\title{
TUGAS DAN FUNGSI \\ BADAN PENANGGULANGAN BENCANA ${ }^{1}$
}

Oleh:

\author{
Ni Ketut Sri Utari \\ Nyoman Mas Aryani
}

A.A. Parwati ${ }^{2}$

\begin{abstract}
The main issue of this research is the enactment of Act No. 24of 2007 regarding Disaster Management, there is a body of disaster management (BNBP and BPBDs) national and regional scale is still in charge, and on the other hand there is an Act No.23/Prp/1959 regarding the State of Emergency.

Type of research is a normative law of the statut or yapproac hand the conceptual approachto find the link between the two laws. The research found: (1) BNP Band BPBD membership structure of the Steeringele mentis civilian officials, professional societies, and also involves the military and police.(2) That the concept of disastersare handled by BNBP or $B P B D$ s similar to the conditions of civil emergency due to natural disasters and social. Relationship between Act23/Prp/1959 with Act No. 24 of 2007, only in situations of disasterorstate of emergency status. Officials who have the authority to determine the status of a state of emergency is the President, or the Governoror Regentequal to civil authorities in emergencies Act No.23/Prp/ 1959.(3) In an emergency situation, boththe law gives special powers to the rulers o fa state of emergency. Relations between the two laws is running paralleland complementary.
\end{abstract}

Keywords: disaster, duties, functions.

${ }^{1}$ Karya ilmiah ini merupakan hasil penelitian yang dibiayai dari dana Dipa BLU Program Studi Magister (S2) Ilmu Hukum PPS UNUD dengan SK Direktur Nomor 1432/UN.14.4/HK/2013, telah dipresentasikan dalam seminar/FGD di Program Magister (S2) Ilmu Hukum pada tanggal 11 Nopember 2013.

${ }^{2}$ Dr. Ni Ketut Sri Utari, SH.,,MH.,dosen pada Program Studi Magister (S2) Ilmu Hukum Program Pascasarjana UNUD dan Fakultas Hukum UNUD, dalam personalia penelitian sebagai Ketua Peneliti. Nyoman Mas Aryani, SH., MH., dosen FH UNUD, dalam personalia penelitian sebagai Anggota Peneliti. A.A. Parwati, SH adalah mahasiswa pada Program Studi Magister (S2) Ilmu Hukum Program Pascasarjana UNUD. 


\section{PENDAHULUAN}

\section{Latar Belakang Masalah}

Lahirnya Undang-undang No. 24

Tahun 2007 Tentang Penanggulangan

Bencana memerintahkan terbentuknya

badan penanggulangan bencana di tingkat

Nasional dan daerah, yakni: Badan

Nasional Penanggulangan Bencana

(BNPB), Badan Penanggulangan Bencana

Daerah Propinsi dan Badan

Penanggulangan Bencana Daerah

Kabupaten atau Kota yang bersifat rutin dan tetap. Di sisi lain ada undang-undang penetapan keadaan bahaya (UU No. 23/ PERPU/ Tahun 1959). Pengertian bencana menurut Undang-undang No.24 Tahun 2007 adalah:

"peristiwa atau rangkaian peristiwa yang mengancam dan mengganggu kehidupan dan penghidupan masyarakat yang disebabkan, baik oleh faktor alam dan/atau faktor non alam maupun faktor manusia sehingga mengakibatkan timbulnya korban jiwa manusia, kerusakan lingkungan, kerugian harta benda, dan dampak psikologis."(Pasal 1 angka 1 UU 24 Tahun 2007).

Ada tiga katagori potensi bencana menurut Pasal 1 angka 2,3,4 Undangundang No.24 Tahun 2007, yaitu:

1) Bencana alam: antara lain gempa bumi, letusan gunung api, angin topan, longsor, kekeringan, kebakaran hutan/ lahan karena faktor alam, hama, penyakit tanaman, epidemik, wabah, kejadian luar biasa, dan kejadian antariksa

2) Bencana non alam: antara lain kebakaran hutan/ lahan karena tindakan manusia, kecelakaan transportasi, kegagalan konstruksi/ tehnologi, dampak industri, ledakan nuklir, pencemaran lingkungan dan kegiatan keantariksaan.

3) Bencana sosial antara lain kerusuhan sosial, konflik sosial dalam masyarakat yang sering terjadi.

Setiap bencana pasti menggambarkan keadaan darurat atau keadaan bahaya, ini menyebabkan adanya kerancuan pemahaman tentang hubungan antara hukum keadaan bahaya dan peraturan mengenai penanggulangan bencana. Masalah yang timbul diidentifikasi antara lain:

a) Apakah BNPB (Badan Penanggulangan Bencana Nasional) dan BPBD (Badan Penanggulangan Bencana Daerah) sebagai pengganti penguasa darurat sipil karena adanya bencana khususnya dalam keadaan tanggap darurat?

b) Rumusantentangbencana non alam yang disebabkan faktor manusia /point 2) dan bencana sosial/ point 3) sangat terbuka, sehingga timbul pertanyaan 
apakah tugas badan penangulangan bencana termasuk bencana dalam keadaan darurat militer dan bencana dalam keadaan darurat perang? Kalau memang benar, maka siapa pemegang Komando ketika bencana terjadi?

c) Bagaimana hubungan antara UU No. 23/ PERPU/ Tahun 1959 yang sampai dewasa ini masih berlaku, tetapi sama sekali tidak dicantumkan sebagai dasar hukum dalam konsideran mengingat dalam Undang-undang No.24 Tahun $2007 ?$

Pertanyaan-pertanyaan di atas sangat perlu penjelasan, karena adanya sistem norma yang tumpang tindih sehingga menjadi kabur. Perlu dilakukan penelusuran peraturan-peraturan pelaksanaan di bawah undang-undang untuk mencari jawaban terhadap permasalahan: $\quad$ Struktur Badan Penanggulangan Bencana, Tugas dan Fungsi Badan Penanggulangan Bencana dan Komando dalam Keadaan Tanggap Darurat Bencana.

\section{METODE PENELITIAN}

Ilmu hukum adalah ilmu yang suigeneris, yang memiliki ciri khas tersendiri, yang bersifat preskriptif atau das solen atau apa yang seharusnya. Hukum adalah konsep yang abstrak, yang bisa diamati dalam kehidupan manusia hanya gejala-gejala dari hukum.Ilmu hukum bukan ilmu empiris dan tidak bebas nilai. ${ }^{3}$ Pendekatan penelitian hukum ada empat macam yakni pendekatan Peraturan Perundang-undangan, Kasus, Perbandingan, Konseptual. ${ }^{4}$

Metode pendekatan dalam penelitian ini adalah pendekatan peraturan perundang-undangan (statutes approach) dan pendekatan konseptual (conceptual approach).Tipe penelitian ini adalah penelitian hukum normatif yang pada dasarnya menggunakan kajian sistematik, mencari hubungan hukum antara UU N0.23 Prp. 1959 dan UU No. 24 Tahun 2007 Tentang Penanggulangan Bencana. Apakah hubungan ini bersifat kontradiksi atau meniadakan yang satu oleh yang lain, atau masih berjalan saling melengkapi dalam implementasinya. Pendekatan konseptual khususnya mencari pengertian "bencana" dan "komando" antara kedua undang-undang tersebut.

a. Sumber Bahan Hukum:

3 Peter Mahmud Marzuki, 2008, Pengantar Ilmu Hukum, Edisi I. cet 1, Jakarta: Penerbit Kencana, h. 27-35.

4 A Hamid S. Attamimi, 1990,Peranan Keputusan Presiden Dalam Penyelenggaraan Pemerintahan Negara. (Disertasi). Jakarta: Fakultas Pasca Sarjana Univesitas Indonesia, h.94. 
Sumber bahan hukum terdiri dari bahan hukum primer, bahan hukum sekunder dan tertier. Sumber bahan hukum primer adalah peraturan perundang-undangan yang akan diteliti antara lain: UU No. 23/ PERPU/ Tahun 1959 Tentang Pencabutan UU N0.74 Tahun 1957 (LN.No.160 Tahun 1957) dan Penetapan Keadaan Bahaya; UU No. 2 Tahun 2002 Tentang Kepolisian Negara Republik Indonesia; UU No. 34 Tahun 2004 Tentang Tentara Nasional Indonesia; Undang-Undang Nomor 32 Tahun 2004 tentang Pemerintahan Daerah sebagaimana telah diubah beberapa kali, terakhir dengan UndangUndang Nomor 12 Tahun 2008 tentang Perubahan Kedua atas Undang-Undang Nomor 32 Tahun 2004 Tentang Pemerintahan Daerah; Undang-Undang Nomor 24 Tahun 2007 Tentang Penanggulangan; Peraturan Pemerintah Nomor 38 Tahun 2007 tentang Pembagian Urusan Pemerintahan Antara Pemerintah, Pemerintahan Daerah Provinsi dan Pemerintahan Daerah Kabupaten/Kota; Peraturan Pemerintah Nomor 41 Tahun 2007 tentang Organisasi Perangkat Daerah; Peraturan Pemerintah Republik Indonesia Nomor 21 Tahun 2008 Tentang Penyelenggaraan Penanggu- langan Bencana; Peraturan Pemerintah Nomor 22 Tahun 2008 tentang Pendanaan dan Pengelolaan Bantuan Bencana; Peraturan Pemerintah Nomor 23 Tahun 2008 tentang Peran Serta Lembaga Internasional dan Lembaga Asing Non pemerintah dalam Penanggulangan Bencana; Peraturan Presiden Nomor 8 Tahun 2008 tentang Badan Nasional Penanggulangan Bencana; Peraturan Menteri Dalam Negeri Nomor 46 Tahun 2008 tentang Pedoman Organisasi dan Tata Kerja Badan Penanggulangan Bencana Daerah; Peraturan Kepala Badan Nasional Penaggulangan Bencana Nomor 3 Tahun 2008 Tentang Pembentukan Badan Penanggulangan Bencana Daerah; Pedoman BNPB yang lain-lain bersifat tehnis sangat banyak.

Sumber bahan hukum sekunder: adalah literatur yang menunjang untuk memahami sumber hukum primer. Sumber bahan hukum tertier berupa kamus-kamus hukum.

b. Tehnik Pengumpulan Bahan Hukum.

Tehnik pengumpulan bahanbahan hukum dengan sistem kartu/kutipan, dan menyimpannya di media komputer. Tahap-tahap pengumpulan bahan dilakukan langkah-langkah sebagai berikut: 
Melakukan inventarisasi: tentang peraturan-perundangan terkait dengan tujuan penelitian untuk penelusuran latar belakang pembentukan aturan hukum, dengan mengkaji, untuk memahami ide-ide pemikiran yang melandasi perumusan norma tersebut; dan menelusuri buku-buku literatur yang terkait; Penelahaan isi bahanbahan yang telah dikumpulkan, Mengutip bahan-bahan yang relevan., dan Melakukan klasifikasi bahan yang telah terkumpul berdasarkan substansi.

b. Analisa Bahan Hukum:Melakukan analisa konten (isi) terhadap dokumen hukum, Merumuskan asas-asas umum hukum yang dijadikan dasar analisis, Melakukan telaah atas isu hukum berdasarkan bahan-bahan yang telah dikumpulkan, Menarik kesimpulan dalam bentuk argumentasi yang menjawab isu hokum, Memberikan preskripsi berdasarkan argumentasi yang telah dibangun dan Menyusun hasil laporan.

\section{HASIL DAN PEMBAHASAN}

1. Struktur Badan Penanggulangan Bencana

Dari penulusuran struktur badan penanggulangan bencana dapat kesimpu- lan bahwa badan penanggulangan bencana ini merupakan lembaga rutin setingkat menteri tetapi non departemen. Tugas utamanya menangani bencana.Konsep bencana yang ditangani mirip dengan bencana dalam status darurat sipil seperti yang dituangkan dalam tabel 1 dalam Pendahuluan disajikan lagi sebagai berikut.

Tabel 1. Perbandingan Rumusan Keadaan Darurat antara UU No. 23/ PERPU/Tahun 1959 dan UU No.24 Tahun 2007

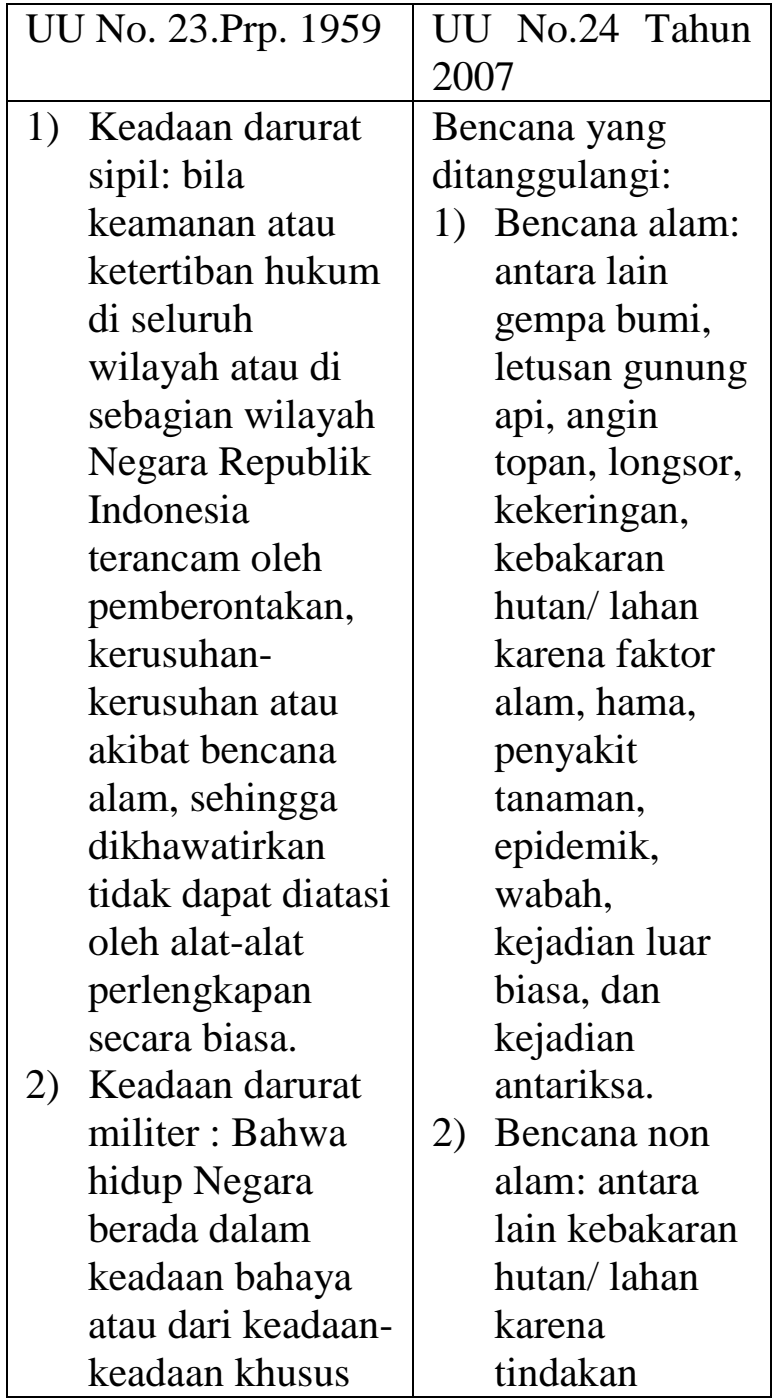


ternyata ada atau dikhawatirkan ada gejala-gejala yang dapat membahayakan hidup Negara

3) Keadaan Perang: Timbul perang atau bahaya perang atau dikhawatirkan perkosaan wilayah Negara Republik Indonesia dengan cara apapun juga. manusia, kecelakaan transportasi, kegagalan konstruksi/ tehnologi, dampak industri, ledakan nuklir, pencemaran lingkungan dan kegiatan keantariksaan.

3) Bencana sosial antara lain kerusuhan sosial, konflik sosial dalam masyarakat yang sering terjadi.

Dari tabel di atas dapat dilihat bahwa pengertian bencana dalam UU No.24 Tahun 2007 hampir mirip dengan keadaan bahaya dalam status darurat Sipil, tetapi jangkauannya lebih luas, bukan saja gangguan terhadap keamanan dan ketertiban seperti fokus utama UU No. 23.Prp. 1959, juga masalah epidemik, wabah, hama tanaman, dan bencana lain.BNPB dan BPBD inilah yang sekarang menangani keadaan-keadaan itu

Dilihat dari struktur keanggotaan BNPB dan BPBD dibandingkan dengan penguasa keadaan darurat seperti dalam UU No.23 Prp.1959 yang dituangkan dalam tabel berikut:
Tabel: 2. Perbandingan Komando Dalam Keadaan Darurat

\begin{tabular}{|c|c|c|}
\hline Tingkat & $\begin{array}{c}\text { Penguasa } \\
\text { Keadaan Darurat } \\
\text { Sipil } \\
\text { UU No 23 Prp } \\
1959\end{array}$ & $\begin{array}{c}\mathrm{BNBP} / \mathrm{BPB} \\
\mathrm{D}\end{array}$ \\
\hline $\begin{array}{c}\text { Nasiona } \\
1\end{array}$ & $\begin{array}{ll}\text { Presiden, } \\
\text { dibantu } \\
\text { 1) } & \text { Menteri } \\
& \text { Pertama } \\
\text { 2) } & \text { Menteri } \\
& \text { Keamanan/P } \\
\text { ertahanan } \\
\text { 3) Mendagri } \\
\text { 4) Menlu } \\
\text { 5) Kastaf AD } \\
\text { 6) Kastaf AL } \\
\text { 7) Kastaf AU } \\
\text { 8) Ka } \\
\text { Kepolisian } \\
\text { Negara }\end{array}$ & $\begin{array}{l}\text { Dalam hal } \\
\text { terjadi } \\
\text { keadaan } \\
\text { tanggap } \\
\text { darurat } \\
\text { Presiden } \\
\text { menunjuk } \\
\text { Komandan } \\
\text { atas usul } \\
\text { BNBP. } \\
\text { Unsur } \\
\text { Pengarah } \\
\text { Penanggulan } \\
\text { gan Bencana } \\
\text { 1. masyarak } \\
\text { at } \\
\text { profesion } \\
\text { al. } \\
\text { 2. unsur } \\
\text { pejabat } \\
\text { pemerint } \\
\text { ah terdiri } \\
\text { dari } \\
\text { perwakil } \\
\text { an: } \\
\text { a. Kemente } \\
\text { rian } \\
\text { Koordina } \\
\text { tor } \\
\text { Bidang } \\
\text { Kesejaht } \\
\text { eraan } \\
\text { Rakyat; } \\
\text { b. Departe } \\
\text { men } \\
\text { Dalam } \\
\text { Negeri; } \\
\text { c. Departe } \\
\text { men }\end{array}$ \\
\hline
\end{tabular}




\begin{tabular}{|c|c|c|}
\hline & & $\begin{array}{ll}\text { Sosial; } \\
\text { d. } & \begin{array}{l}\text { Departe } \\
\text { men }\end{array} \\
& \text { Pekerjaa } \\
\text { n Umum; } \\
\text { e. } & \text { Departe } \\
\text { men } \\
\text { Kesehata } \\
\text { n; } \\
\text { f. } & \text { Departem } \\
\text { en } \\
\text { Keuangan } \\
\text { g. } \\
\text { Departe } \\
\text { men } \\
\text { Perhubun } \\
\text { gan; } \\
\text { h. Departe } \\
\text { men } \\
\text { Energi } \\
\text { dan } \\
\text { Sumber } \\
\text { Daya } \\
\text { Mineral; } \\
\text { i. Kepolisia } \\
\text { n Negara } \\
\text { Republik } \\
\text { Indonesia } \\
\text {; dan } \\
\text { j. Tentara } \\
\text { Nasional } \\
\text { Republik } \\
\text { Indonesi } \\
\text { a }\end{array}$ \\
\hline $\begin{array}{c}\text { Propins } \\
\text { i }\end{array}$ & $\begin{array}{l}\text { Kepala Daerah } \\
\text { Propinsi/Guber } \\
\text { nur } \\
\text { dibantu oleh: } \\
\text { 1) Seorang } \\
\text { Komandan } \\
\text { Militer } \\
\text { Tertinggi } \\
\text { Daerah ybs } \\
\text { 2) Seorang } \\
\text { Kepala } \\
\text { Kepolisian } \\
\text { Daerah ybs }\end{array}$ & $\begin{array}{l}\text { Dalam hal } \\
\text { terjadi } \\
\text { keadaan } \\
\text { tanggap } \\
\text { darurat } \\
\text { Gubernur } \\
\text { menunjuk } \\
\text { Komando } \\
\text { atas usul } \\
\text { BPBD.(Perat } \\
\text { uran BNBP } \\
\text { No.3/2008) } \\
\text { Unsur }\end{array}$ \\
\hline
\end{tabular}

\begin{tabular}{|c|c|c|}
\hline & $\begin{array}{l}\text { 3) Seorang } \\
\text { Pengawas/ } \\
\text { Kepala } \\
\text { Kejaksaan } \\
\text { Daerah ybs }\end{array}$ & $\begin{array}{l}\text { Pengarah } \\
\text { Penanggulan } \\
\text { gan Bencana } \\
\text { 1. masyarak } \\
\text { at profe- } \\
\text { sional. } \\
\text { 2. Dari } \\
\text { unsur } \\
\text { pejabat } \\
\text { pemerint } \\
\text { ah daerah } \\
\text { dan } \\
\text { instansi } \\
\text { TNI, } \\
\text { Kepo- } \\
\text { lisian }\end{array}$ \\
\hline $\begin{array}{c}\text { Kabupa } \\
\text { ten }\end{array}$ & $\begin{array}{l}\text { Serendah- } \\
\text { rendahnya } \\
\text { Kepala Daerah } \\
\text { Tk.II dibantu: } \\
\text { 1) Seorang } \\
\text { Komandan } \\
\text { Militer } \\
\text { Tertinggi } \\
\text { Daerah ybs } \\
\text { 2) Seorang } \\
\text { Kepala } \\
\text { Kepolisian } \\
\text { Daerah ybs } \\
\text { 3) Seorang } \\
\text { Pengawas } \\
\text { Kepala } \\
\text { Kejaksaan } \\
\text { Daerah ybs }\end{array}$ & $\begin{array}{l}\text { Dalam hal } \\
\text { terjadi } \\
\text { keadaan } \\
\text { tanggap } \\
\text { darurat } \\
\text { Bupati / Wali } \\
\text { kota } \\
\text { menunjuk } \\
\text { Komando } \\
\text { atas usul } \\
\text { BPBD. } \\
\text { (Peraturan } \\
\text { BNBP } \\
\text { No.3/2008) } \\
\text { Unsur } \\
\text { Pengarah } \\
\text { Penanggulan } \\
\text { gan Bencana } \\
\text { 1. masyara } \\
\quad \text { kat } \\
\text { profesio } \\
\text { nal. } \\
\text { 2. Dari } \\
\text { unsur } \\
\text { pejabat } \\
\text { pemerint } \\
\text { ah/ } \\
\text { instansi } \\
\text { TNI, } \\
\text { Kepolisi } \\
\text { an }\end{array}$ \\
\hline
\end{tabular}


Sumber: Diolah dari ketentuan peraturan perundangan terkait

Dari tabel di atas dapat dilihat bahwa UU No.23 Prp 1959 menekankan persoalan tentang siapa penguasa dalam keadaan darurat dan lebih focus pada gangguan keamanan dan ketertiban, sehingga penguasa keadaan darurat sipil melibatkan unsur TNI, Kepolisian dan Kejaksaan.

Keadaan bencana yang ditangani BNPB dan BPBD mirip dengan keadaan yang dikelompokan dalam status darurat sipil. Penguasa yang dapat menetapkan status keadaan darurat bencana adalah Presiden, Gubernur dan Bupati sama dengan penguasa keadaan darurat sipil dalam UU No.23 Prp 1959. Dari struktur keanggotaan BNPB dan BPBD struktur keanggotaan unsur Pengarah adalah pejabat sipil dan masyarakat professional disamping TNI dan POLRI. Hubungan antara UU No.23 Prp 1959 dengan UU No.24 Tahun 2007, hanya dalam situasi terjadinya bencana.Pengertian bencana dalam UU No.24 Tahun 2007 hampir mirip dengan keadaan bahaya dalam status darurat Sipil, tetapi jangkauannya lebih luas, bukan saja gangguan terhadap keamanan dan ketertiban seperti fokus utama UU No. 23.Prp. 1959, juga masalah epidemik, wabah, hama tanaman, dan bencana kebakaran dll.

\section{Tugas dan Fungsi Badan}

\section{Penanggulangan Bencana}

Dari penelusuran terhadap tugas dan fungsi badan penanggulangan bencana (BNPB dan BPBD), tampak jelas bahwa ada paradigm baru dalam penanggulangan bencana yakni prioritas pada upaya preventif, kesiapsiagaan dalam menghadapi bencana baik mental berupa pengetahuan maupun kesiagaan secara financial yang terus menerus dalam menangani bencana secara terencana, terpadu, terkoordinasi dan menyeluruh.

Dilihat dari tugas dan fungsinya sangat menonjol sifat koordinatif yang melibatkan seluruh komponen pemerintahan, masyarakat dan pihak swasta dan LSM profesional semacam gerakan dalam upaya mewujudkan visi "Ketangguhan Bangsa Dalam Menghadapi Bencana".Penekan utama adalah menghadapi bencana alam terutama pasca Tsunami Aceh dan Lumpur Lapindo. Hal ini dapat disimpulkan dari landasan pemikiran (ratio legis) dari UU No. 24 Tahun 2007 bahwa Kondisi Indonesia yang berada di wilayah yang memiliki kondisi geografis, geologis, hidrologis dan demografis yang rawan terhadap terjadinya bencana dengan frekuensi yang cukup 
tinggi, sehingga memerlukan penanganan yang sistematis, terpadu, dan terkoordinasi. Setiap bencana pasti menggambarkan keadaan darurat atau keadaan bahaya. Ini menyebabkan adanya kerancuan pemahaman tentang hubungan antara hukum keadaan bahaya dan peraturan mengenai penanggulangan bencana. Konsep mengenai bencana yang menimbulkan masalah terutama mengenai bencana sosial seperti yang terungkap dalam latar belakang masalah penelitian ini. Apakah BNBP dan BPBD bertugas dan berfungsi dalam menghadapi bencana pembrontakan bersenjata atau keadaan darurat militer dan keadaan perang.

Hal ini belum jelas terungkap, karena bila dilihat dari Rencana Nasional Penanggulangan Bencana 2010-2014 titik berat prioritas pada penanggulangan bencana karena faktor alam dan konflik sosial.Tetapi dikaji dari Visi dan misi, tugas dan fungsi dapat disimpulkan dalam keadaan bencana sosial seperti keadaan darurat militer maupun keadaan perang BNBP dan BPBD tetap menjalankan fungsinya khususnya untuk melindungi masyarakat sipil.

Bila kondisi dalam keadaan darurat militer atau darurat perang, maka kemungkinan Penguasa keadaan darurat adalah Komandan Militer sesuai dengan ketentuan UU No. 23 Prp 1959. BNBP dan BPBD ada di garis belakang untuk perlindungan masyarakat sipil atau pengungsi. Dari hasil analisis ini dapat ditarik kesimpulan bahwa BNBP dan atau BPBD tetap menjalankan tugasnya dalam bencana perang atau dalam keadaan darurat militer untuk perlindungan masyarakat.

\section{Komando Dalam Keadaan Tanggap Darurat}

Penentuan atau pernyataan status keadaan darurat bencana adalah Presiden, Gubernur atau Bupati wali kota sesuai dengan status keadaan darurat bencana dan komandan (orang yang memberi komando) ditunjuk atas usul badan penanggulangan bencana di wilayah itu. Penunjukan komandan dengan memperhatikan kebijakan penanggulangan bencana dalam arti disesuaikan dengan kondisi bencana.Sesuai dengan perintah Pasal 49 Peraturan Presiden RI No.8 Tahun 2008 Tentang BNPB.Prinsip Koordinasi dan professional sangat diperlukan dalam penanggulangan bencana. Misalnya kalau adanya bencana wabah, maka komandannya bisa ditangan ahli atau unsur Departemen Kesehatan, kalau serangan hama bisa dari unsur Departemen 
Pertanian, kalau keamanan dan ketertiban ada ditangan Polri atau TNI.

Kaitan dengan kondisi darurat kewenangan-kewenangan khusus dimiliki oleh BNBP atau BPBD dan akan disandingkan kewenangan khusus penguasa keadaan darurat sipil dengan badan penanggulangan bencana.

Tabel. 3. Perbandingan Kewenangan Khusus dalam Keadaan Darurat.

\begin{tabular}{|c|c|}
\hline $\begin{array}{c}\text { UU No. } 23 \text { Tahun } \\
1959\end{array}$ & $\begin{array}{c}\text { Badan } \\
\text { Penaggulangan } \\
\text { Bencana }\end{array}$ \\
\hline $\begin{array}{l}\text { Penguasa Darurat } \\
\text { Sipil, dapat: } \\
\text { 1) mengeluarkan } \\
\text { peraturan- } \\
\text { peraturan polisi } \\
\text { (pasal 10); } \\
\text { 2) meminta } \\
\text { keterangan- } \\
\text { keterangan dari } \\
\text { pegawai negeri } \\
\text { (dicatat disini, } \\
\text { bahwa dalam } \\
\text { keadaan } \\
\text { darurat militer/ } \\
\text { keadaan perang } \\
\text { penguasa dapat } \\
\text { mewajibkan } \\
\text { setiap orang } \\
\text { untuk } \\
\text { memberikan } \\
\text { keterangan) } \\
\text { (pasal 12; } \\
\text { selanjutnya } \\
\text { pasal 23 dan } \\
\text { 36, pada huruf } \\
\text { c). } \\
\text { 3) } \\
\text { peraturan- } \\
\text { peraturan }\end{array}$ & $\begin{array}{l}\text { 1) pengerahan } \\
\text { sumber daya } \\
\text { manusia; } \\
\text { 2) pengerahan } \\
\text { peralatan; } \\
\text { 3) pengerahan } \\
\text { logistik; } \\
\text { 4) imigrasi, cukai, } \\
\text { dan karantina; } \\
\text { 5) perizinan; } \\
\text { 6) pengadaan } \\
\text { barang/jasa; } \\
\text { 7) pengelolaan dan } \\
\text { pertanggungjaw } \\
\text { aban uang } \\
\text { dan/atau barang; } \\
\text { penyelamatan; } \\
\text { dan } \\
\text { 8) komando untuk } \\
\text { memerintahkan } \\
\text { instansi/lembaga } \\
\text {. (Pasal 21-24 } \\
\text { PP No. 21 } \\
\text { Tahun 2008). }\end{array}$ \\
\hline
\end{tabular}

tentang pembatasan pertunjukanpertunjukan apapun juga serta semua pencetakan, penerbitan dan pengumuman apapun juga (pasal 13);

4) menggeledah tiap-tiap tempat (pasal 14);

5) memeriksa dan mensita barang-barang yang disangka dipakai atau akan dipakai untuk merusak keamanan (pasal 15);

6) mengambil atau memakai barang-barang dinas umum (pasal 16);

7) Mengetahui percakapan melalui radio, membatasi pemakaian kode-kode dan sebagainya (pasal 17);

8) membatasi rapat-rapat umum dan lain sebagainya dan membatasi atau melarang/mem asuki dan memakai gedung (pasal 18);

9) membatasi 
orang berada di luar rumah (pasal 19);

10) memeriksa badan dan pakaian (pasal 20);

11) memerintah dan mengatur badan-badan kepolisian, pemadam kebakaran mengeluarkan peraturanperaturan polisi (pasal 10);Penjelasan Umum Perpu No. 23 Tahun 1959

Sumber: Diolah dari Perpu No. 23 Tahun 1959dan PP No. 21 Tahun 2008

Dari perbandingan dalam tabel di atas dapat dilihat adanya pengaturan yang berbeda mengenai kewenangan khusus atau istimewa dalam kondisi darurat.UU No.23 Prp 1959 penekanan pada keadaan keamanan dan ketertiban yang terganggu yang memungkinkan adanya pembatasan hak-hak asasi manusia bila diperlukan, sementara UU No.24 Tahun 2007 memberi kewenangan untuk menggunakan biaya siap pakai dan fungsi pengerahan sumber daya manusia dan alat dan prosedurprosedur khusus (lihat angka 1) sampai 8 dalam tabel).Penguasa keadaan darurat tidak boleh sembarangan menyatakan keadaan darurat dan menyalahgunakan kekuasaan, prinsipnya adalah "kalau perlu"atau mendesak dan hanya merupakan upaya mengatasi keadaan darurat tersebut, ada asasnecisitas" dan asas proporsionalitas. Penguasa tertinggi dalam keadaan darurat adalah Presiden, landasan konstitusionalnya adalah Pasal 10, Pasal 11 dan Pasal 12 UUD NRI 1945.

Atas dasar itulah maka dalam Pasal 3 UU No.23 PrpTahun 1959 bahwa Presiden adalah Penguasa Keadaan darurat yang tertinggi dengan dibantu oleh Menteri Pertahanan, Menteri Dalam Negeri, Menteri Luar Negeri, Kepala Staf TNI dan Kepala Staf Kepolisian Negara. Keadaan Darurat dibagi dalam 3 tahap atau jenjang dengan maksud untuk lebih memperhitungkan derajat kegentingan keadaan, maka peraturan ini mengenal 3 tingkatan keadaan bahaya: keadaan darurat sipil, keadaan darurat militer dan keadaan perang.

Dari yang dipaparkan di atas tampak jelas bahwa dalam keadaan darurat maka kewenangan penguasa keadaan darurat sangat istimewa, dan masyarakat dapat kehilangan kebebasannya.Walaupun demikian tujuan utamanya adalah keselamatan umum. 
Hubungan antara UU No.23 Prp

1959 dengan UU No.24 Tahun 2007, hanya dalam situasi terjadinya bencana.Sementara menurut UU No.24 Tahun 2007 badan penanggulangan bencana bersifat rutin dan permanen, pengertian bencana lebih luas, maka unsur masyarakat dan pejabat sipil dan masyarakat professional dilibatkan disamping TNI dan POLRI.Dalam keadaan tanggap darurat $\mathrm{BNBP}$ dan $\mathrm{BPBD}$ juga memiliki kewenangan-kewenangan khusus seperti penggunaan dana siap pakai; pengerahan sumber daya manusia; pengerahan peralatan; pengerahan logistik; imigrasi, cukai, dan karantina; perizinan; pengadaan barang/jasa; pengelolaan dan pertanggungjawaban uang dan/atau barang; penyelamatan; dan komando untuk memerintahkan instansi/lembaga seperti Polri dan TNI.

Prinsip terkoordinasi dan terintegrasi dengan lembaga pemerintah baik pusat maupun daerah, Tentara Nasional Indonesia dan Kepolisian Negara Republik Indonesia dengan memperhatikan kebijakan penyelenggaraan penanggulangan bencana dan ketentuan peraturan perundangundangan, merupakan kata kunci untuk menyimpulkan bahwa UU No.23 Prp 1959 masih berlaku dan harus diperhatikan, sehingga antara UU No.23 Prp 1959 dan UU No.24 Tahun 2007 berjalan parallel dan saling melengkapi.

\section{SIMPULAN DAN SARAN}

\section{Simpulan}

Dari penelusuran peraturan perundang-undangan yang berkaitan dengan keadaan darurat bencana maka dapat disimpulkan sebagai berikut:

a. Dari penulusuran struktur badan penanggulangan bencana dapat disimpulkan bahwa badan penanggulangan bencana ini merupakan lembaga rutin/ tetap setingkat menteri tetapi non departemen di bawah Kordinasi Menko Kesra. Tugas utamanya menangani bencana. Konsep bencana yang ditangani mirip dengan bencana dalam status darurat sipil menurut UU No.23 Prp Tahun1959, kondisi yang diatur apabila benar terjadi bahaya, yang merupakan tindakan sementara di mana dalam terminologi UU No.24 Tahun 2007 disebut keadaan tanggap darurat bencana. Hubungan antara UU No.23 Prp 1959 dengan UU No.24 Tahun 2007, hanya dalam situasi terjadinya bencana yang intinya dirinci sebagai berikut: 
1) Penguasa yang dapat menetapkan status keadaan darurat bencana adalah Presiden, atau Gubernur atau Bupati sama dengan penguasa keadaan darurat sipil dalam UU No.23 Prp 1959.

2) Dari struktur keanggotaan BNPB dan BPBD struktur keanggotaan unsur Pengarah adalah pejabat sipil, masyarakat professional, dan juga melibatkan TNI dan POLRI.

3) Pengertian bencana dalam UU No.24 Tahun 2007 hampir mirip dengan keadaan bahaya dalam status darurat Sipil, tetapi jangkauannya lebih luas, bukan saja gangguan terhadap keamanan dan ketertiban seperti fokus utama UU No. 23.Prp. 1959, juga masalah epidemik, wabah, hama tanaman, dan bencana kekeringan dan kebakaran hutan.

b. Dari penelusuran terhadap tugas dan fungsi badan penanggulangan bencana (BNPB dan BPBD), tampak jelas bahwa ada paradigm baru dalam penanggulangan bencana yakni prioritas pada upaya preventif, kesiapsiagaan dalam menghadapi bencana baik mental berupa pengetahuan maupun kesiagaan secara financial dalam menghadapi bencana secara terencana, terpadu, terkoordinasi dan menyeluruh. Dilihat dari tugas dan fungsinya sangat menonjol sifat koordinatif yang melibatkan seluruh komponen pemerintahan, masyarakat dan pihak swasta dan LSM profesional semacam gerakan dalam upaya mewujudkan visi "Ketangguhan Bangsa Dalam Menghadapi Bencana.” Hasil kajian mengenai tugas dan fungsi badan penanggulangan bencana dapat dirinci sebagai berikut:

1) Penekan utama adalah menghadapi bencana alam terutama pasca Tsunami Aceh dan Lumpur Lapindo. Hal ini dapat disimpulkan dari landasan pemikiran UU No. 24 Tahun 2007 bahwa kondisi Indonesia yang berada di wilayah yang memiliki kondisi geografis, geologis, hidrologis dan demografis yang rawan terhadap terjadinya bencana dengan frekuensi yang cukup tinggi, sehingga memerlukan penanganan yang sistematis, terpadu, dan terkoordinasi.

2) Setiap bencana pasti menggambarkan keadaan darurat atau keadaan bahaya. Ini menyebabkan adanya kerancuan pemahaman tentang hubungan antara hukum keadaan bahaya dan 
peraturan

mengenai

penanggulangan bencana. Konsep

mengenai bencana yang

menimbulkan masalah terutama mengenai bencana sosial seperti yang terungkap dalam latar belakang masalah penelitian ini. Apakah BNBP dan BPBD bertugas dan berfungsi dalam menghadapi bencana sosial seperti pembrontakan bersenjata atau keadaan darurat militer dan keadaan perang. Hal ini belum jelas terungkap, karena bila dilihat dari Rencana Nasional Penanggulangan Bencana 2010-2014 titik berat prioritas pada penanggulangan bencana karena faktor alam dan konflik sosial Tetapi dikaji dari visi dan misi, tugas dan fungsi BNBP dan BPBD dapat disimpulkan keadaan bencana seperti keadaan darurat militer maupun keadaan perang, BNBP dan BPBD tetap menjalankan fungsinya khususnya untuk melindungi masyarakat sipil.

c. Bila kondisi dalam keadaan darurat militer atau darurat perang, maka kemungkinan Penguasa keadaan darurat di daerah adalah Komandan Militer sesuai dengan ketentuan UU No. 23 Prp 1959. BNBP dan BPBD ada di garis belakang untuk perlindungan masyarakat sipil atau pengungsi. Titik temu antara UU No.23 Prp 1959 dengan UU No.24 Tahun 2007, dalam situasi terjadinya bencana, atau dalam keadaan tanggap darurat bencana. Hubungan dapat dirinci sebagai berikut:

1) Dalam situasi darurat kedua undang-undang ini memberi kewenangan istimewa kepada penguasa keadaan darurat.UU No.23 Prp 1959 penekanan pada keadaan keamanan dan ketertiban yang terganggu yang memungkinkan adanya pembatasan hak-hak asasi manusia bila diperlukan, sementara UU No.24 Tahun 2007 memberi kewenangan untuk menggunakan biaya siap pakai dan fungsi komando pengerahan sumber daya manusia dan alat dan prosedur-prosedur khusus/ istimewa lainnya.

2) Pasal 48 Peraturan Presiden RI No.8 Tahun 2008 Tentang BNPB yang menekankan adanya prinsip terkoordinasi dan terintegrasi dengan lembaga pemerintah baik pusat maupun daerah, Tentara Nasional Indonesia dan Kepolisian Negara Republik Indonesia dengan 
memperhatikan kebijakan

penyelenggaraan penanggulangan

bencana dan ketentuan peraturan perundang-undangan. Ketentuan ini merupakan kata kunci untuk menyimpulkan bahwa UU No.23 Prp 1959 masih berlaku dan harus diperhatikan. Sehingga antara UU No.23 Prp 1959 dan UU No.24 Tahun 2007 berjalan parallel dan saling melengkapi.

\section{Saran}

UU No. 23/ PERPU/ Tahun 1959 adalah undang-undang yang lama dengan istilah pejabat yang tidak sesuai dengan kondisi sekarang. Disarankan untuk perbaikan redaksi dengan tidak mengubah substansi karena masih relevan dengan tujuan melindungi eksistensi negara dalam keadaan bahaya dan memberi batasan yang jelas tentang kewenangan penguasa keadaan darurat, pembatasan dan perlindungan hak-hak asasi manusia. Pernah ada usaha untuk mencabut dan mengganti dengan menyusun RUU Keadaan Bahaya masa pemerintahan Presiden Abdurachman Wahid (Gus Dur) tetapi sampai saat ini masih berupa rancangan saja.

DAFTAR PUSTAKA

\section{BUKU}

Asshiddiqie, Jimly,2007, Hukum Tata Negara Darurat, PT Raja Grafindo Persada, Jakarta.

Attamimi., A Hamid S,1990, Peranan Keputusan Presiden

DalamPenyelenggaraan

Pemerintahan Negara. (Disertasi), Fakultas Pasca Sarjana Univesitas Indonesia, Jakarta.

Marzuki, Peter Mahmud, 2005, Penelitian Hukum, Edisi I Cetakan ke-4. Penerbit Kencana, Jakarta. ,2008, Pengantar Ilmu Hukum. Edisi I. cet 1. Penerbit Kencana, Jakarta.

Sihombing, Herman., 1995, Hukum Tata Negara Darurat di Indonesia, Penerbit Djambatan, Jakarta.

\section{PERATURAN PERUNDANG- UNDANGAN}

UUD Negara Republik Indonesia Tahun 1945

Undang-Undang Republik Indonesia No. 23/PERPU/ Tahun 1959 Tentang Pencabutan Undang-Undang Nomor 74 Tahun 1957 (Lembaran Negara RI Tahun 1957 Nomor 160 dan Penetapan Keadaan Bahaya.

Undang-Undang Republik Indonesia Nomor 23 Tahun 1997 Tentang Lingkungan Hidup, Lembaran Negara Republik Indonesia Tahun 1997 Nomor 68, Tambahan Lembaran Negara Republik Indonesia Nomor 3699.

Undang-Undang Republik Indonesia Nomor 40 Tahun 2007 Tentang 
Perseroan Terbatas, Lembaran Negara Republik Indonesia Tahun 2007 Nomor 106, Tambahan Lembaran Negara Republik Indonesia Nomor 4756.

Undang-Undang Republik Indonesia Nomor 2 Tahun 2002 Tentang Kepolisian Negara Republik Indonesia, Lembaran Negara Republik Indonesia Tahun 2002 Nomor 2, Tambahan Lembaran Negara Republik Indonesia Nomor 4168.

Undang-Undang Republik Indonesia Nomor 34 Tahun 2004 Tentang Tentara Nasional Indonesia, Lembaran Negara Republik Indonesia Tahun 2004 Nomor 127, Tambahan Lembaran Negara Republik Indonesia Nomor 4439.

Undang-Undang Republik Indonesia Nomor 24 Tahun 2007 Tentang Penanggulangan Bencana, Lembaran Negara Republik Indonesia Tahun 2007 Nomor 66, Tambahan Lembaran Negara Republik Indonesia Nomor 4723.
Peraturan Pemerintah Republik Indonesia Nomor 21 Tahun 2008 Tentang Penyelenggaraan Penanggulangan Bencana, Lembaran Negara Republik Indonesia Tahun 2008 Nomor 42, Tambahan Lembaran Negara Republik Indonesia Nomor 4828.

Peraturan Presiden Republik Indonesia Nomor 8 Tahun 2008 Tentang Badan Nasional Penanggulangan Bencana, ditetapkan 26 Januari 2008.

Peraturan Kepala Badan Nasional Penaggulangan Bencana Nomor 3 Tahun 2008 Tentang Pedoman Pembentukan Badan Penanggulangan Bencana Daerah. ditetapkan 11 Nopember 2008.

\section{III.INTERNET}

http://www.bnpb.go.id. Rencana Nasional Penanggulangan Bencana RI 2010-2014

http://www.bnpb.go.idRencana Strategis (Renstra) Badan Nasional Penanggulangan Bencana (BNPB) Tahun 2010-2014. 